\title{
Front Matter: Volume 7204
}

, "Front Matter: Volume 7204," Proc. SPIE 7204, Micromachining and Microfabrication Process Technology XIV, 720401 (10 March 2009); doi: $10.1117 / 12.828729$

Event: SPIE MOEMS-MEMS: Micro- and Nanofabrication, 2009, San Jose, California, United States 


\title{
PROCEEDINGS OF SPIE
}

\section{Micromachining and Microfabrication Process Technology XIV}

\author{
Mary-Ann Maher \\ Jung-Chih Chiao \\ Paul J. Resnick \\ Editors
}

27 January 2009

San Jose, California, United States

Sponsored by

SPIE

Symposium Cosponsors

Texas Instruments Inc. (United States)

Nanolnk, Inc. (United States)

The Photonics Center at Boston University (United States)

Ozen Engineering, Inc. (United States)

Published by

SPIE 
The papers included in this volume were part of the technical conference cited on the cover and title page. Papers were selected and subject to review by the editors and conference program committee. Some conference presentations may not be available for publication. The papers published in these proceedings reflect the work and thoughts of the authors and are published herein as submitted. The publisher is not responsible for the validity of the information or for any outcomes resulting from reliance thereon.

Please use the following format to cite material from this book:

Author(s), "Title of Paper," in Micromachining and Microfabrication Process Technology XIV, edited by Mary-Ann Maher, Jung-Chih Chiao, Paul J. Resnick, Proceedings of SPIE Vol. 7204 (SPIE, Bellingham, WA, 2009) Article CID Number.

ISSN 0277-786X

ISBN 9780819474506

Published by

SPIE

P.O. Box 10, Bellingham, Washington 98227-0010 USA

Telephone +1 3606763290 (Pacific Time) · Fax +1 3606471445

SPIE.org

Copyright (C) 2009, Society of Photo-Optical Instrumentation Engineers

Copying of material in this book for internal or personal use, or for the internal or personal use of specific clients, beyond the fair use provisions granted by the U.S. Copyright Law is authorized by SPIE subject to payment of copying fees. The Transactional Reporting Service base fee for this volume is $\$ 18.00$ per article (or portion thereof), which should be paid directly to the Copyright Clearance Center (CCC), 222 Rosewood Drive, Danvers, MA 01923. Payment may also be made electronically through CCC Online at copyright.com. Other copying for republication, resale, advertising or promotion, or any form of systematic or multiple reproduction of any material in this book is prohibited except with permission in writing from the publisher. The CCC fee code is 0277-786X/09/\$18.00.

Printed in the United States of America.

Publication of record for individual papers is online in the SPIE Digital Library.

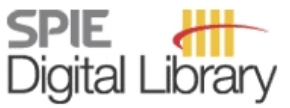

SPIEDigitalLibrary.org

Paper Numbering: Proceedings of SPIE follow an e-First publication model, with papers published first online and then in print and on CD-ROM. Papers are published as they are submitted and meet publication criteria. A unique, consistent, permanent citation identifier (CID) number is assigned to each article at the time of the first publication. Utilization of CIDs allows articles to be fully citable as soon they are published online, and connects the same identifier to all online, print, and electronic versions of the publication. SPIE uses a six-digit CID article numbering system in which:

- The first four digits correspond to the SPIE volume number.

- The last two digits indicate publication order within the volume using a Base 36 numbering system employing both numerals and letters. These two-number sets start with 00, 01, 02, 03, 04, $05,06,07,08,09,0 A, 0 B \ldots 0 Z$, followed by 10-1Z, 20-2Z, etc.

The CID number appears on each page of the manuscript. The complete citation is used on the first page, and an abbreviated version on subsequent pages. Numbers in the index correspond to the last two digits of the six-digit CID number. 


\section{Contents}

v Conference Committee

vii The high versatility of silicon based micro-optical modulators (Plenary Paper) [7208-101]

H. Schenk, Fraunhofer Institute for Photonic Microsystems (Germany)

\section{SESSION 1 DEVICES}

720402 Cost-effective method of manufacturing a 3D MEMS optical switch [7204-01]

E. Carr, P. Zhang, D. Keebaugh, K. Chau, Glimmerglass Networks (United States)

720403 Uncooled infrared and terahertz detectors based on micromechanical mirror as a radiation pressure sensor [7204-02]

G. P. Berman, B. M. Chernobrod, A. R. Bishop, Los Alamos National Lab. (United States);

V. N. Gorshkov, Los Alamos National Lab. (United States) and Institute of Physics (Ukraine)

720404 A novel fabrication method for semiconductor ring lasers that ensures optimal electrical pumping [7204-04]

N. Dutta, J. P. Gupta, J. A. Murakowski, D. W. Prather, Univ. of Delaware (United States)

720405 Optical fiber packaging for MEMS interfacing [7204-05]

J. Mireles, Jr., M. A. Garcia, R. C. Ambrosio, Univ. Autónoma de Ciudad Juárez (Mexico);

E. J. Garcia, Sandia National Labs. (United States); W. Calleja, C. Reyes, Instituto Nacional de Astrofísica, Óptica y Electrónica (Mexico)

720406 A high sensitivity hall sensor fabricated on a SOI wafer using surface micromachining technique [7204-06]

N. Singh, H. V. Estrada, Univ. of North Carolina at Charlotte (United States)

720407 Sharpened transparent micronozzle fabrication for cell membrane piercing [7204-07]

E. M. Campo, M. J. Lopez-Martinez, Ctr. Nacional de Microelectrónica (Spain);

E. Fernández, E. Ibañez, L. Barros, C. Nogues, Univ. Autònoma de Barcelona (Spain);

J. Esteve, J. A. Plaza, Ctr. Nacional de Microelectrónica (Spain)

SESSION 2 PROCESS: LASERS, MILLING, CMP

720409 Stretchable multilayer self-aligned interconnects fabricated using excimer laser photoablation and in situ masking (Invited Paper) [7204-09]

K. L. Lin, K. Jain, Univ. of Illinois at Urbana-Champaign (United States)

7204 OA Pulsed laser breaking technique for glass substrates [7204-11]

C.-H. Tsai, W.-H. Chang, Huafan Univ. (Taiwan)

7204 OC Two-photon polymerization for fabrication of three-dimensional micro- and nanostructures over a large area [7204-13]

M. Malinauskas, V. Purlys, M. Rutkauskas, R. Gadonas, Vilnius Univ. (Lithuania) 
7204 OD A study of the influence of cutting parameters on micromilling of steel with cubic boron nitride (CBN) tools [7204-14]

F. Klocke, F. Quito, K. Arntz, A. Souza, Fraunhofer Institute for Production Technology

(Germany)

\section{SESSION 3 SPECIAL SESSION ON CAD}

$72040 \mathrm{~J} \quad 1 / f$ noise in single-walled carbon nanotube films [7204-21]

A. Behnam, G. Bosman, A. Ural, Univ. of Florida (United States)

\section{POSTER SESSION}

7204 ON Polymeric nanosieves fabricated by UV lithography [7204-26]

L. Gutierrez-Rivera, L. Cescato, Univ. of Campinas (Brazil)

7204 OP Nanorod measurement-layer separate structure for nanorod-character measurement, simulation, and application as sensor devices [7204-29]

M.-K. Leem, J.-U. Park, C.-M. Kim, K.-J. Kim, S.-H. Yeom, W.-Y. Choi, Kyungpook National Univ. (Korea, Republic of); W.-S. Kang, J.-H. Kim, Ajou Univ. (Korea, Republic of); S.-W. Kang, Kyungpook National Univ. (Korea, Republic of)

Author Index 


\title{
Conference Committee
}

\author{
Symposium Chair \\ Albert K. Henning, Nanolnk, Inc. (United States) \\ Symposium Cochair \\ Thomas J. Suleski, The University of North Carolina at Charlotte \\ (United States) \\ Conference Chairs \\ Mary-Ann Maher, SoftMEMS (United States) \\ Jung-Chih Chiao, The University of Texas at Arlington (United States) \\ Paul J. Resnick, Sandia National Laboratories (United States) \\ Program Committee \\ Mu Chiao, The University of British Columbia (Canada) \\ Debabani Choudhury, HRL Laboratories, LLC (United States) \\ Eric Donzier, Consultant (United Kingdom) \\ Sanjay Krishna, The University of New Mexico (United States) \\ Tamal Mukherjee, Carnegie Mellon University (United States) \\ Yu-Chuan Su, National Tsing Hua University (Taiwan) \\ T. C. Yih, Oakland University (United States) \\ Nan Zhang, General MEMS Corporation (United States) \\ Session Chairs \\ 1 Devices \\ Mary-Ann Maher, SoftMEMS (United States) \\ 2 Process: Lasers, Milling, CMP \\ Nan Zhang, General MEMS Corporation (United States) \\ 3 Special Session on CAD \\ Metin Ozen, Ozen Engineering, Inc. (United States)
}


Downloaded From: https://www.spiedigitallibrary.org/conference-proceedings-of-spie on 26 Apr 2023

Terms of Use: https://www.spiedigitallibrary.org/terms-of-use 